Chelan, Wash.). Nitrogen for this purge-type

\section{Elevated Carbon Dioxide Storage of 'Anjou' Pears Using Purge-controlled Atmosphere}

\author{
Stephen R. Drake ${ }^{1}$ \\ U.S. Department of Agriculture, Agricultural Research Service, Tree Fruit \\ Research Laboratory, 1104 North Western Avenue, Wenatchee, WA 98801
}

Additional index words. Pyrus communis, controlled-atmosphere storage

\begin{abstract}
Anjou' pears (Pyrus communis L.) were placed in controlled-atmosphere (CA) storage immediately after harvest $(<24$ hours) or after a 10 -day delay in refrigerated storage, and held there for 9 months at $1 \mathrm{C}$. Oxygen in all atmospheres was $1.5 \%$ and $\mathrm{CO}_{2}$ was at either $1 \%$ or $3 \%$. Atmospheres in the flow-through system were computercontrolled at $\pm \mathbf{0 . 1 \%}$. After removal from CA storage, pears were evaluated immediately and after ripening at $21 \mathrm{C}$ for 8 days. Pears stored in $3 \% \mathrm{CO}_{2}$ were firmer, greener, and displayed less scald, internal breakdown, and stem-end decay than pears stored in $1 \%$ $\mathrm{CO}_{2}$. In addition, no internal discoloration of 'Anjou' pears was evident when held with $3 \%$ $\mathrm{CO}_{2}$.'Anjou' pears held in $3 \%$. $\mathrm{CO}$, retained the ability to ripen after long-term storage. A 10-day delay in atmosphere establishment had little or no influence on the long-term keeping quality or ripening ability of 'Anjou' pears.
\end{abstract}

Atmospheres of $1 \%$ to $2 \% \mathrm{O}_{2}$ and $<1.0 \%$ $\mathrm{CO}_{2}$ are recommended for controlled-atmosphere (CA) storage of 'Anjou' pears (Hansen and Mellenthin, 1979; Hardenburg et al., 1986). Using $2 \%$ or less $\mathrm{O}_{2}$ for long-term pear storage reduced loss of firmness, acidity, and greenness, and scald severity (Chen et al., 1981; Mellenthin et al., 1980; Richardson and Meheriuk, 1989). Elevated $\mathrm{CO}_{2}$ in long-term Claypool, 1948; Hansen, 1957). Although higher $\mathrm{CO}_{2}$ enhances storage life of pears (Claypool, 1973; Hansen and Mellenthin, 1962), the results are conflicting because they involve cultivar, maturity, tree vigor, and storage delay. Exposing 'Anjou' pears to prestorage high- $\mathrm{CO}_{2}$ treatments for short periods of time prolongs storage life (Wang and Mellenthin, 1975). Removing $\mathrm{CO}_{2}$ to a level of $\leq 1 \%$.is a costly and time-consuming operation (Blanpied, 1988; Wealti and Cavalieri, 1990). been conducted with static systems where fruit is held in the same atmosphere over the entire storage period and only $\mathrm{O}_{2}$ and $\mathrm{CO}_{2}$ levels are regulated. Many new CA facilities employ a flow-through system where fruit is exposed to a flowing atmosphere of desired concentrations. This research was conducted to determine the quality of 'Anjou' pears stored under two $\mathrm{CO}_{2}$ levels where the atmospheres

Received for publication 25 June 1993. Accepted for publication 2 Nov. 1993. I thank the Washington State Tree Fruit Research Commission for its financial support of this project. Use of a company or product name by the department does not imply approval or recommendation of the product to the exclusion of others that may also be suitable. The cost of publishing this paper was defrayed in part by the payment of page charges, Under postal regulations, this paper therefore must be hereby marked advertisement solely to indicate this fact. 'Research Horticulturist. pear storage can cause brown core (Allen and

Previous research in CA pear storage has were established at different times after harvest in a flow-through-type facility.

\section{Materials and Methods}

This study was conducted over 3 years using 'Anjou' pears grown in the Wenatchee, Wash., district. During the first year, eight boxes (four individual lots) were obtained from a commercial warehouse 1 day after harvest. Pears from three orchards with a known history of differences in storage quality were used in two of the years. Pears were divided into four groups. CA of $1.5 \% \mathrm{O}_{2}$ and $1 \% \mathrm{CO}_{2}$ or $1.5 \% \mathrm{O}_{2}$ and $3 \% \mathrm{CO}_{2}$ at $1 \mathrm{C}$ were established within $24 \mathrm{~h}$ after harvest on two groups. Identical CA regimes were established on the remaining two groups after 10 days in cold storage (1C). Pears were stored for 9 months before evaluation. All atmospheres were established and maintained throughout the storage period at $\pm 0.1 \%$ using a computer control system (Technical Consulting Services,
CA system was supplied by a Generon Membrane Separation System (Generon, Houston). Bottled $\mathrm{CO}_{2}$ was used as the $\mathrm{CO}_{2}$ source.

Storage evaluation consisted of 20 pears for all combinations of atmosphere, time delay, and replication. Ten pears were evaluated immediately after removal from storage, and the other 10 were allowed to ripen for 8 days at ambient temperature (20C) before evaluation. Quality factors evaluated were external and internal color, firmness, soluble solids concentration (SSC), titratable acidity (TA), carbohydrates, and visible disorders.

External and internal color were determined with a CR300 Minolta chromameter (Osaka, Japan) using the Hunter L, a, b mode and calibrated with a white plate (no. 11133144). Three values for external color were determined around the circumference of each fruit, and the average value for 10 fruit was reported. Internal color was measured by cutting each fruit in half equatorially and immediately reading the exposed flesh surface of the calyx ${ }^{-}$end; the average value for 10 fruit was reported. A model EP1 pressure tester (Lake City, Kelowna, B.C., Canada) equipped with a 7.8-mm head was used to determine firmness. Juice prepared from pear slices was titrated to $\mathrm{pH} 8.2$ with $0.1 \mathrm{~N} \mathrm{NaOH}$ and values were expressed as percentage of malic acid. SSC was determined with an Abbe-type refractometer calibrated at 20C. Carbohydrates were determined by the high-performance liquid chromatography method described by Bio-Rad (Bio-Rad, Richmond, Calif.). Disorders $\left(\mathrm{CO}_{2}\right.$ injury, scald, internal breakdown, cork spot, and stem decay) were evaluated by visual assessment and expressed as the percentage of fruit affected. Analysis of variance was determined by MSTAT (1988) as a factorial design. Based on significant $\mathrm{F}$ test, means were separated by Duncan's multiple range test.

\section{Results and Discussion}

'Anjou' pears stored in 3\% $\mathrm{CO}_{2}$ were $41 \%$ firmer $(15.6 \mathrm{~N})$ than those stored in $1 \% \mathrm{CO}_{2}$ after 9 months of storage (Table 1). When
Table 1. Firmness, soluble solids concentration (SSC), titratable acidity (TA), and SSC: TA ratio for 'Anjou' pears as influenced by controlled-atmosphere storage conditions.

\begin{tabular}{|c|c|c|c|c|}
\hline Treatment & $\begin{array}{c}\text { Firmness } \\
\text { (N) }\end{array}$ & $\begin{array}{c}\text { SSC } \\
\left({ }^{\circ} \text { Brix }\right)\end{array}$ & $\begin{array}{c}\text { TA } \\
(\% \text { malic })\end{array}$ & $\begin{array}{c}\text { SSC : TA } \\
\text { ratio }\end{array}$ \\
\hline \multicolumn{5}{|c|}{ Atmosphere $\times$ ripening $(\text { days })^{2}$} \\
\hline \multicolumn{5}{|c|}{$1.5 \% \mathrm{O}_{2}+1 \% \mathrm{CO}_{2}$} \\
\hline 0 & $37.8 b^{y}$ & $13.0 \mathrm{ab}$ & $0.24 \mathrm{a}$ & $55 \mathrm{~b}$ \\
\hline 8 & $19.1 \mathrm{c}$ & $12.5 \mathrm{c}$ & $0.21 \mathrm{c}$ & $61 \mathrm{a}$ \\
\hline \multicolumn{5}{|c|}{$1.5 \% \mathrm{O}_{2}+3 \% \mathrm{CO}_{2}$} \\
\hline 0 & $53.4 \mathrm{a}$ & $13.1 \mathrm{a}$ & $0.24 \mathrm{a}$ & $54 \mathrm{~b}$ \\
\hline 8 & $19.6 \mathrm{c}$ & $12.7 \mathrm{~b}$ & $0.22 \mathrm{~b}$ & $59 \mathrm{c}$ \\
\hline \multicolumn{5}{|c|}{ Atmosphere $\times$ delay (days) ${ }^{x}$} \\
\hline \multicolumn{5}{|c|}{$1.5 \% \mathrm{O}_{2}+1 \% \mathrm{CO}_{2}$} \\
\hline 0 & $26.2 \mathrm{~b}$ & $12.8 \mathrm{~b}$ & $0.22 \mathrm{~b}$ & 58 a \\
\hline 10 & $30.2 \mathrm{~b}$ & $12.8 \mathrm{~b}$ & $0.22 \mathrm{~b}$ & $58 \mathrm{a}$ \\
\hline \multicolumn{5}{|c|}{$1.5 \% \mathrm{O}_{2}+3 \% \mathrm{CO}_{2}$} \\
\hline 0 & $36.0 \mathrm{a}$ & $12.8 \mathrm{~b}$ & $0.24 \mathrm{a}$ & $54 \mathrm{~b}$ \\
\hline 10 & $37.4 \mathrm{a}$ & $13.1 \mathrm{a}$ & $0.22 \mathrm{~b}$ & $59 \mathrm{a}$ \\
\hline
\end{tabular}

${ }^{x}$ Pears were held at $21 \mathrm{C}$ for 8 days for ripening.

${ }^{y}$ Mean separation within columns and treatment groups by Duncan's multiple range test $(P \leq 0.05)$.

${ }^{x}$ Atmosphere establishment delayed 10 days after harvest; pears were held at $1 \mathrm{C}$ during this period. 
allowed to ripen for 8 days at ambient temperature, pears from either $1 \%$ or $3 \% \mathrm{CO}_{2}$ storage ripened to a similar firmness level (19 $\mathrm{N})$. When CA was established immediately after harvest $(<24 \mathrm{~h})$, pears stored in $3 \% \mathrm{CO}_{2}$ were $37 \%$ firmer $(9.8 \mathrm{~N})$ than pears stored in $1 \% \mathrm{CO}_{2}$ (Table 1). When pears were in cold storage (1C) for 10 days before atmosphere establishment, the difference in firmness was $24 \%(7.2 \mathrm{~N})$ in favor of pears that were stored in $3 \%$ rather than in $1 \% \mathrm{CO}^{2}$.

There was no difference in the SSC of 'Anjou' pears due to $\mathrm{CO}_{2}$ concentration. There was a loss in SSC when pears were ripened for 8 days. Ripened pears from 3\% $\mathrm{CO}_{2}$ lost less SSC during ripening (3\%) than pears from $1 \%$ $\mathrm{CO}_{2}(4 \%)$ (Table 1). There was some difference (2\%) in SSC of pears when CA establishment was delayed 10 days but only when stored in the $3 \% . \mathrm{CO}_{2}$ atmosphere (Table 1). Differences for individual carbohydrate concentrations (sucrose, fructose, glucose, and sorbitol) between pears from the two $\mathrm{CO}_{2}$ atmospheres were minimal (data not shown). Neither $\mathrm{CO}_{2}$ content of the atmosphere nor a 10-day delay in atmosphere establishment resulted in a change in the individual carbohydrate concentrations in 'Anjou' pears.

TA values were similar for pears stored in $1 \%$ or $3 \% \mathrm{CO}_{2}$. When ripened for 8 days, 'Anjou' pears from the $3 \% \mathrm{CO}_{2}$ storage did not lose as much acid as pears from the $1 \% \mathrm{CO}_{2}$ storage environment (Table 1). A 10-day delay in CA establishment resulted in pears with similar acid values regardless of $\mathrm{CO}_{2}$ level. Pears from the $3 \% \mathrm{CO}_{2}$ storage were higher initially in TA, or when CA was established in $\leq 24 \mathrm{~h}$, but when CA establishment was delayed, TA content was identical (Table 1).

Pears from both $\mathrm{CO}_{2}$ storage environments had similar SSC : TA ratios after ripening (Table 1). Those in $1 \% \mathrm{CO}_{2}$ had a higher SSC : TA ratio when atmosphere was established immediately, but the SSC : TA ratio was the same for the two $\mathrm{CO}_{2}$ levels when atmosphere establishment was delayed 10 days (Table 1).

'Anjou' pears stored in 3\% $\mathrm{CO}_{2}$ were greener (higher hue value) than pears stored in $1 \% \mathrm{CO}_{2}$ at removal and after ripening (Table 2). Pears lost green pigmentation during ripening regardless of the $\mathrm{CO}_{2}$ level in storage, but this loss in color was slightly greater with pears stored in $1 \% \mathrm{CO}_{2}$ than those stored in $3 \%$ $\mathrm{CO}_{2}$. This difference in color was also evident when Hunter "L" values were considered. Fruit from 3\% $\mathrm{CO}_{2}$ had a lower Hunter "L" value (indicative of a darker surface color than pears stored in $1 \% \mathrm{CO}_{2}$ ), but no difference was present after 8 days of ripening.

The difference in Hunter color values between pears from $1 \%$ or $3 \% \mathrm{CO}_{2}$ at removal and after ripening was visually quite apparent. Hue values (arctan b/a values) also indicated a much greener (less yellow) pear surface when pears were stored in $3 \%$ than in $1 \% \mathrm{CO}_{2}$. Hue values, after ripening, also indicated that pears stored in $3 \% \mathrm{CO}_{2}$ changed color from green to yellow more slowly than those stored in $1 \%$ $\mathrm{CO}_{2}$. A 10-day delay in atmosphere establishment had no influence on Hunter color " $a$ " and "L" values or hue.
Table 2. External and internal color of 'Anjou' pears as influenced by controlled-atmosphere storage conditions.

\begin{tabular}{|c|c|c|c|c|c|c|}
\hline \multirow[b]{3}{*}{ Treatments } & \multicolumn{6}{|c|}{ Hunter color } \\
\hline & \multicolumn{3}{|c|}{ External } & \multicolumn{3}{|c|}{ Internal } \\
\hline & $\mathbf{L}$ & a & Hue & $\mathrm{L}$ & b & Hue \\
\hline \multicolumn{7}{|c|}{ Atmosphere $\times$ ripening $(\text { days })^{z}$} \\
\hline \multicolumn{7}{|c|}{$1.5 \% \mathrm{O}_{2}+1 \% \mathrm{CO}_{2}$} \\
\hline 0 & $63.7 a^{y}$ & $-3.6 c$ & $97.6 \mathrm{~b}$ & $69.3 \mathrm{a}$ & $18.7 \mathrm{a}$ & $84.7 \mathrm{~b}$ \\
\hline 8 & $65.6 \mathrm{a}$ & $0.4 \mathrm{a}$ & $88.8 \mathrm{~d}$ & $69.4 \mathrm{a}$ & $18.3 \mathrm{a}$ & $84.9 \mathrm{ab}$ \\
\hline \multicolumn{7}{|c|}{$1.5 \% \mathrm{O}_{2}+3 \% \mathrm{CO}_{2}$} \\
\hline 0 & $57.6 \mathrm{~b}$ & $-5.9 \mathrm{~d}$ & $102.8 \mathrm{a}$ & $72.1 \mathrm{a}$ & $18.4 \mathrm{a}$ & $86.3 \mathrm{a}$ \\
\hline 8 & $66.3 \mathrm{a}$ & $-2.1 \mathrm{~b}$ & $94.2 \mathrm{c}$ & $70.5 \mathrm{a}$ & $18.0 \mathrm{a}$ & $84.3 \mathrm{ab}$ \\
\hline \multicolumn{7}{|c|}{ Atmosphere $\times$ delay $(\text { days })^{x}$} \\
\hline \multicolumn{7}{|c|}{$1.5 \% \mathrm{O}_{2}+1 \% \mathrm{CO}_{2}$} \\
\hline 0 & $62.8 \mathrm{a}$ & $-1.0 \mathrm{a}$ & $91.9 \mathrm{~b}$ & $67.8 \mathrm{a}$ & $18.4 \mathrm{a}$ & $84.5 \mathrm{a}$ \\
\hline 8 & $66.5 \mathrm{a}$ & $2.1 \mathrm{a}$ & $94.4 \mathrm{~b}$ & $70.8 \mathrm{a}$ & $18.6 \mathrm{a}$ & $85.2 \mathrm{a}$ \\
\hline \multicolumn{7}{|c|}{$1.5 \% \mathrm{O}_{2}+3 \% \mathrm{CO}_{2}$} \\
\hline 0 & $58.5 \mathrm{a}$ & $-4.1 b$ & $98.6 \mathrm{a}$ & $69.8 \mathrm{a}$ & $17.9 \mathrm{a}$ & $85.0 \mathrm{a}$ \\
\hline 8 & $65.0 \mathrm{a}$ & $-3.9 \mathrm{~b}$ & $98.4 \mathrm{a}$ & $72.8 \mathrm{a}$ & $18.5 \mathrm{a}$ & $85.6 \mathrm{a}$ \\
\hline
\end{tabular}

${ }^{\mathrm{Z}}$ Pears were held at $21 \mathrm{C}$ for 8 days for ripening.

${ }^{x}$ Mean separation within columns within groups by Duncan's multiple range test $(P \leq 0.05)$.

${ }^{\mathrm{x}}$ Atmosphere establishment delayed 10 days after harvest; pears were held at $1 \mathrm{C}$ during this period.
Hansen and Mellenthin (1962) and Claypool (1973) reported that high $\mathrm{CO}_{2}$ in the storage atmosphere will result in a darker internal color of 'Anjou' pears. Internal color was not affected for pears stored in $3 \% \mathrm{CO}_{2}$ regardless of ripening time or delay in atmosphere establishment (Table 2). Internal Hunter "L" values were identical for pears from both $\mathrm{CO}_{2}$ atmospheres before and after ripening, regardless of delay in CA establishment. Hunter "b" values or yellowness were also similar for all treatments. Internal hue values were not influenced by either ripening time or a delay for atmosphere establishment, but there was a change in pears from the different $\mathrm{CO}_{2}$ atmospheres before ripening. This difference in hue values was slight (1.6 units) and was considered of no commercial consequence even though a change of 1.0 unit is visually detectable (Hunter and Harold, 1987).

Scald, internal breakdown, and stem decay (Table 3) were significantly reduced in 'Anjou' pears that were stored in $3 \% \mathrm{CO}_{2}$ when compared to $1 \% \mathrm{CO}_{2}$. Internal breakdown (core browning) was of particular concern, but in this study pears had a lower incidence of the disorder in $3 \% \mathrm{CO}_{2}$ than in $1 \% \mathrm{CO}_{2}$. Pears from one of the orchards used in this study have a history of internal breakdown and are poor candidates for CA storage, but reduced internal breakdown was also apparent when pears from this orchard were stored in $3 \%$ $\mathrm{CO}_{2}$. Dilley (1993), working with apples (Malus domestica Borkh.), suggested that purge CA may flush volatile compounds that contribute to disorders. Gast (1993) noted a reduction in volatile production when apples were stored in a purge CA system. A higher incidence of cork spot was found in fruit stored in $3 \% \mathrm{CO}_{2}(11 \%)$ than in $1 \% \mathrm{CO}_{2}(5 \%)$. No external surface injury from $3 \% \mathrm{CO}_{2}$ was evident after long-term storage.

After 8 days of ripening, scald and internal breakdown were more apparent, but cork spot was less evident than immediately after storage (Table 3). The increase (34\%) in scald was of major concern, particularly if no use of scald control chemicals is required by law. The increase in internal breakdown, although significant, was much less (19\%). After ripening, stem decay was less apparent, presumably because the stem dried. A 10-day delay in atmosphere establishment resulted in reduced cork spot but increased internal breakdown with no change in amount of scald or stem decay present. A delay in atmosphere establishment might allow the fruit to become more acclimated to one environment before subjecting fruit to a second environment.

Maintaining a higher $\mathrm{CO}_{2}$ in the storage atmosphere reduces operational cost (Wealti and Cavalieri, 1990). Three percent $\mathrm{CO}_{2}$ in the
Table 3. Incidence of disorders and stem decay of 'Anjou' pears as influenced by controlled-atmosphere storage conditions.

\begin{tabular}{|c|c|c|c|c|}
\hline Treatments & $\begin{array}{c}\text { Scald } \\
(\%)\end{array}$ & $\begin{array}{c}\text { Internal } \\
\text { breakdown } \\
(\%)\end{array}$ & $\begin{array}{l}\text { Cork } \\
\text { spot } \\
(\%) \\
\end{array}$ & $\begin{array}{c}\text { Stem } \\
\text { decay } \\
(\%) \\
\end{array}$ \\
\hline \multicolumn{5}{|l|}{ Atmosphere } \\
\hline $1.5 \% \mathrm{O}_{2}+1 \% \mathrm{CO}_{2}$ & $22.3 \mathrm{a}^{2}$ & $40.3 \mathrm{a}$ & $5.1 \mathrm{~b}$ & $14.4 \mathrm{a}$ \\
\hline $1.5 \% \mathrm{O}_{2}+3 \% \mathrm{CO}_{2}$ & $12.3 \mathrm{~b}$ & $21.0 \mathrm{~b}$ & $10.9 \mathrm{a}$ & $2.1 \mathrm{~b}$ \\
\hline \multicolumn{5}{|l|}{ Ripening (days) } \\
\hline 0 & $0.0 \mathrm{~b}$ & $28.1 \mathrm{~b}$ & $9.8 \mathrm{a}$ & $9.3 \mathrm{a}$ \\
\hline 8 & $34.6 \mathrm{a}$ & $33.4 \mathrm{a}$ & $6.3 \mathrm{~b}$ & $7.3 \mathrm{~b}$ \\
\hline \multicolumn{5}{|l|}{ Delay (days) } \\
\hline 0 & $16.9 \mathrm{a}$ & $28.9 \mathrm{~b}$ & $12.2 \mathrm{a}$ & $8.1 \mathrm{a}$ \\
\hline 10 & $17.6 \mathrm{a}$ & $32.5 \mathrm{a}$ & $3.8 \mathrm{~b}$ & $8.4 \mathrm{a}$ \\
\hline
\end{tabular}

${ }^{\bar{z}}$ Mean separation within pairs by analysis of variance $(P \leq 0.05)$.

${ }^{\mathrm{Y}}$ Pears were held at $21 \mathrm{C}$ for 8 days for ripening.

${ }^{\mathrm{x}}$ Atmosphere establishment delayed 10 days after harvest; pears were held at $1 \mathrm{C}$ during this period. 
storage atmosphere is well above the recommended $\mathrm{CO}_{2}$ atmosphere of $1 \%$ to $1.5 \%$ for 'Anjou' pears. In this study there were definite quality advantages for 'Anjou' pears stored at $3 \% \mathrm{CO}_{2}$ for 9 months relative to $1 \% \mathrm{CO}_{2}$ storage. These quality benefits include reductions in loss of firmness and greenness and disorders. A 10-day delay between harvest and atmosphere establishment had little or no influence on the long-term keeping quality or ripening ability of 'Anjou' pears.

\section{Literature Cited}

Allen, F.W. 1939. Influence of carbon dioxide in lengthening the life of Bartlett pears. Proc. Amer. Soc, Hort. Sci. 37:473-478.

Allen, F.W. and L.L. Claypool. 1948. Modified atmosphere in relation to the storage life of Bartlett pears. Proc. Amer. Soc. Hort. Sci. 59:192-204.

Blanpied, G.D. 1988. Items of interest for apple operators in New York, New England and beyond. Cornell Fruit Handling and Storage Nwsl., August.
Chen, P.M., R.A. Spotts, and W.M. Mellenthin. 1981. Stem-end decay and quality of low oxygen stored 'd'Anjou' pears. J. Amer. Soc. Hort. Sci. 106:522-527.

Claypool, L.L. 1973. Further studies on controlled atmosphere storage of 'Bartlett' pears. J. Amer. Soc. Hort. Sci. 98:289-293.

Dilley, D.R. 1993. Effect on apple quality of purge vs. static systems for atmosphere control for CA storage. Proc. Wash. Tree Fruit Postharvest Conf. 9:83-85.

Gast, W.A., Jr. 1993. Purge vs. static: Is there a quality difference? Proc. Wash. Tree Fruit Postharvest Conf. 9:82.

Hansen, E. 1957. Reactions of Anjou pears to carbon dioxide and oxygen content of the storage atmosphere. Proc. Amer. Soc. Hort. Sci. 69:110115.

Hansen, E. and W.M. Mellenthin. 1962. Factors influencing susceptibility of pears to carbon dioxide injury. Proc. Amer. Soc. Hort. Sci. 80:146-153.

Hansen, E. and W.M. Mellenthin. 1979. Commercial handling and storage practices for winter pears. Oregon State Univ. Agr. Expt. Sta. Rpt. 550.
Harlenburg, R.E., A.E. Watada, and C.Y. Wang. 1986. The commercial storage of fruits, vegetables and florist and nursery stocks. U.S. Dept of Agr., Agr. Hdbk. 66.

Hunter, R.S. and R.W. Harold. 1987. The measurement of appearance, 2nd ed. Wiley, New York,

Mellenthin, W.M., P.M. Chen, and S.B. Kelly. 1980. Low oxygen effects on desert quality, scald prevention and nitrogen metabolism of 'd' Anjou' pear fruit during long term storage. J. Amer. Soc. Hort. Sci. 105:522-527.

MSTAT, 1988. Version 1.0, Michigan State Univ., East Lansing.

Richardson, D.G. and M. Meheriuk. 1989. CA recommendations for pears (including Asian pears), p. 285-302, vol 2. In: J.K. Fellman (ed.). Proc. 5th Intl. Controlled Atmosphere Res. Conf. June 1989, Wenatchee, Wash.

Wang, C.Y. and W.M. Mellenthin. 1975. Effect of short-term high $\mathrm{CO}_{2}$ treatment on storage of 'd'Anjou' pears. J. Amer. Soc. Hort. Sci. 100:492-495.

Wealti, H. and R.P. Cavalieri. 1990. Matching nitrogen equipment to your needs. Tree Fruit Postharvest J. 1:3-13. 